\title{
Corporate social entrepreneurship initiatives against food waste - The case of Lidl in Romania
}

\author{
Ramona CANTARAGIU \\ The Bucharest University of Economic Studies, Bucharest, Romania \\ ramona_cantaragiu@yahoo.com
}

PICBE | 505

\begin{abstract}
Food waste is one of the major global sustainability issues which, in the last few decades, has come to the attention of numerous organizations which have implemented strategies aimed either at preventing food waste, recovering the food and reusing it for human consumption or ensuring that the food unfit for human consumption is recycled into compost, animal feed etc. Previous studies have highlighted that major retailers share a large portion of the responsibility for combating food waste and that they are particularly well-positioned to contribute with a solution to this issue. Thus, the study explores the ways in which food chain responsibility can be incorporated into the overall strategy of large chain retailers through the theoretical framework of corporate social entrepreneurship. Lidl's initiative against food waste in Romania provides the background for the discussion of the means through which the resources owned by these chain retailers can be mobilized in order to help increase the amount of food that is recovered and reused for alleviating the problem of food scarcity among disadvantaged groups. The study highlights the aspects that are necessary for a successful corporate social entrepreneurship initiative aimed at reducing food waste: a) a clear articulation of the problem and solution; $b$ ) the mobilization of actors from the civil society; c) continuous investment; and d) the alignment of the scaling up strategy of the initiative with the retailer's resources. The study concludes that a food waste program based on the principles of corporate social entrepreneurship can generate a sustainable competitive advantage for retailers.
\end{abstract}

Keywords: food waste, social responsibility, corporate social entrepreneurship, retailing industry.

\section{Introduction}

Food waste is a major global concern and has been on the public agenda of national and international institutions for the past couple of decades. In fact, combating food waste became one of the main UN sustainable development goals as the organization established in 2015 that it would take measures in order to reduce to half the amount of global food waste at retail and consumption level by 2030. As a result, numerous public and private institutions have sought to find effective ways to combat food waste by designing and advocating for new public policies, investing in public awareness campaigns about the negative impact of food waste on the society and the environment and fostering social entrepreneurial initiatives that help both consumers and producers reduce the amount of food that reaches the landfills. In spite of these actions, the most recent statistics published by the Food and Agriculture Organization of the UN still show that around one third of the food produced worldwide is wasted and that the problem of food waste is encountered not only in developed countries where almost $40 \%$ of the food waste results at the level of retail and consumption, but also in underdeveloped countries where more than $40 \%$ of the food waste happens as a result of faulty production and harvesting processes (FA0, 2019).

The most recent statics show that Romanians waste around 6,000 tones of food per day, the equivalent of a portion of food for each Romanian, and that, annually more than 2.2 billion kilograms of food end up in Romanian landfills where they contribute to 
environmental pollution (Zugravu, 2018). When compared to the domestic food supply, it is evident that the highest percentages of waste are registered for vegetables and eggs, while the lowest percentages are recorded for cereals, milk and meat (see Table 1). This places Romania on the $9^{\text {th }}$ place in the top of the EU countries with the highest amounts of wasted food after Great Britain, Holland, Germany, France, Poland and Belgium (Moca-Grama, 2018). Most of the food waste is recorded at the level of households (49\%), followed by industrial processes (37\%), while the lowest contributors to food waste in Romania are retailers (7\%) and the agricultural sector (5\%) (Barbu, 2018). What is of major concern is the fact that Romanians spend, on average, more than $40 \%$ of their household income on food, which is twice or thrice as much as people from France or from Switzerland spend (Zugravu, 2018). This information should be read in the context of the severe economic disparities that affect the standard of living of most Romanian people (i.e., one out of four Romanians lives under the poverty line which means that they cannot afford even the most basic necessities) (Deacu, 2018).

Table 1. Statistics regarding food waste in Romania

\begin{tabular}{|c|c|c|c|c|c|c|c|c|c|}
\hline Item & Element & 2006 & 2007 & 2008 & 2009 & 2010 & 2011 & 2012 & 2013 \\
\hline \multirow[t]{3}{*}{ Cereals - Excluding Beer } & Domestic supply quantity & 15775 & 15239 & 14672 & 12972 & 13641 & 16065 & 10620 & 13955 \\
\hline & Waste & 217 & 143 & 203 & 190 & 244 & 327 & 170 & 279 \\
\hline & Waste (\%) & 1.37 & 0.93 & 1.38 & 1.44 & 1.78 & 2.03 & 1.60 & 1.99 \\
\hline \multirow[t]{3}{*}{ Starchy Roots } & Domestic supply quantity & 4223 & 3813 & 3772 & 3738 & 3711 & 3750 & 3141 & 3222 \\
\hline & Waste & 65 & 60 & 60 & 60 & 50 & 60 & 40 & 50 \\
\hline & Waste (\%) & 1.53 & 1.57 & 1.59 & 1.60 & 1.34 & 1.60 & 1.27 & 1.55 \\
\hline \multirow[t]{3}{*}{ Vegetables } & Domestic supply quantity & 4489 & 3531 & 4197 & 4226 & 4254 & 4536 & 3895 & 4285 \\
\hline & Waste & 203 & 151 & 192 & 200 & 202 & 219 & 179 & 197 \\
\hline & Waste (\%) & 4.52 & 4.27 & 4.57 & 4.73 & 4.74 & 4.82 & 4.59 & 4.59 \\
\hline \multirow[t]{3}{*}{ Fruits - Excluding Wine } & Domestic supply quantity & 2941 & 2450 & 2650 & 2667 & 2541 & 2732 & 2401 & 2812 \\
\hline & Waste & 67 & 64 & 53 & 60 & 63 & 54 & 56 & 65 \\
\hline & Waste (\%) & 2.27 & 2.61 & 2.00 & 2.24 & 2.47 & 1.97 & 2.33 & 2.31 \\
\hline \multirow[t]{3}{*}{ Meat } & Domestic supply quantity & 1385 & 1385 & 1388 & 1462 & 1288 & 1192 & 1178 & 1085 \\
\hline & Waste (\%) & 1.87 & 2.09 & 2.37 & 1.77 & 2.01 & 2.26 & 1.35 & 1.19 \\
\hline & Waste & 26 & 29 & 33 & 26 & 26 & 27 & 16 & 13 \\
\hline \multirow[t]{3}{*}{ Eggs } & Domestic supply quantity & 380 & 336 & 362 & 330 & 320 & 334 & 317 & 317 \\
\hline & Waste & 11 & 10 & 11 & 10 & 10 & 10 & 10 & 10 \\
\hline & Waste (\%) & 2.89 & 2.97 & 3.03 & 3.03 & 3.12 & 2.99 & 3.15 & 3.15 \\
\hline \multirow[t]{3}{*}{ Milk - Excluding Butter } & Domestic supply quantity & 6702 & 6503 & 6383 & 6127 & 5373 & 5506 & 5339 & 5390 \\
\hline & Waste & 38 & 38 & 37 & 36 & 32 & 33 & 32 & 32 \\
\hline & Waste (\%) & 0.56 & 0.58 & 0.57 & 0.58 & 0.59 & 0.59 & 0.59 & 0.59 \\
\hline
\end{tabular}

Note: The amounts are measured in 1000 tones. Source: OECD database.

In light of these realities, the Romanian government has decided to implement certain legislative changes that would decrease the amount of food waste and, in particular, increase the amount of food that becomes available/affordable for people living in poverty. In 2019, the government passed the methodology for the implementation of the law on food waste 
which offers fiscal benefits for the retailers that donate food either to social canteens or other organizations that can use the food in order to feed consumers. Various food items excluding alcoholic beverages and unpasteurized fruit and vegetable juices can be donated ten days prior to their expiration date and the expenses with the donated food items can be deducted from the income tax. This has produced the necessary legislative environment for retailers such as Lidl which were willing to collaborate with non-governmental actors in order to reduce the amount of food wasted due to the fact that it is not bought by consumers.

The present study focuses on the efforts made by Lidl Romania to reduce the amount of food wasted at the level of retail by donating the food items that are about to expire to numerous charities that serve the needs of disadvantaged groups. The following sections present the theoretical background and the way in which data was gathered and analyzed for the purpose of understanding the main factors that contribute to the success of corporate social entrepreneurship initiatives in the field of food waste. The final two section present the main results of the investigation and a discussion of the avenues for future research.

\section{Literature review}

Initiatives aimed at combating food waste can be grouped into four main categories: a) strong prevention initiatives aimed at reducing both the production and the consumption of food items (e.g., shared food, meals based on seasonality etc.); b) weak prevention initiatives aimed at the optimization of the various processes along the food supply chain (e.g., smart labels, public awareness campaigns, shelves with discounted products etc.); c) recovery initiatives aimed at ensuring the re-use of avoidable food waste items for human consumption (e.g., food banks, social supermarkets etc.); and d) recycling initiatives aimed at transforming food not fit for human consumption into animal feed, compost or energy (e.g., on-site composting, biogas facilities etc.) (Mourad, 2016). Previous studies on food waste initiatives at the retail level have focused mostly on the logistical aspects involved by the collection and transportation of the food donated by companies to the beneficiaries, highlighting the main issues and the critical success factors (Bonomi et al., 2016; Sarti et al., 2017). Other studies have focused on particular case studies that examined either the social impact created by various types of social entrepreneurship initiatives aimed at combating food waste (e.g., the impact of social supermarkets in Maric \& Knezevic, 2014) or the sustainability and scalability of similar initiatives (e.g., the sustainability of a non-profit cooperative that sells unaesthetically pleasing fruits and vegetables in Ribeiro et al., 2018). For example, Aschemann-Witzel et al. (2017) found that supply-chain initiatives aimed at combating food waste at the consumer level depend on three main factors: collaboration between stakeholders, timing and the nature of the incentives produced for each category of stakeholders. However, what is missing from previous studies is the application of a theoretical framework that allows the preservation of social entrepreneurship principles while also taking into consideration the realities faced by retailers which are for-profit companies. This gap in the literature is addressed by the current paper which employs the theory of corporate social entrepreneurship. Corporate social entrepreneurship has yet to receive a stable and fully accepted definition (Hadad \& Cantaragiu, 2017), but most definitions make reference to the idea of for-profit companies implementing projects that create both social and economic value. For many authors (see Popovici \& Muhcina, 2012), corporate social entrepreneurship is the next stage in the development of corporate social 
responsibility, which makes it particularly suitable for the analysis of the projects aimed at combatting food waste that go beyond the confines of simple CSR projects either through their scale or their longevity.

\section{Research methodology}

This is an exploratory research based on a case study constructed using secondary data PICBE | 508 available online. The case study focuses on the corporate social entrepreneurship strategy employed by a major multinational retail chain in Romania. Data was gathered through online searches during the period February-March 2019 and analyzed based on the following theoretical framework that includes the success factors for corporate social entrepreneurship initiatives:

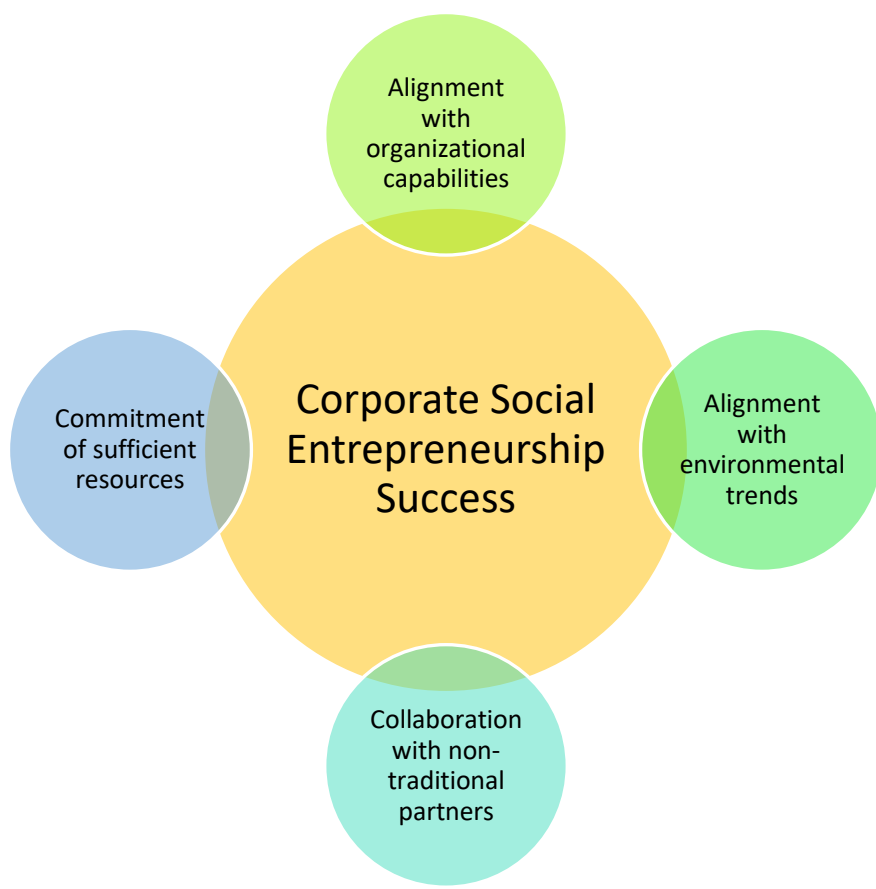

Figure 1. Theoretical framework

Source: Author's own research design.

As previously mentioned, the case study is based on the experience of Lidl with its project "Banca pentru Alimente" which was initiated in 2017 and continued to expand until 2019 (and will continue to do so but this is beyond the scope of the present paper). Data was gathered both from the reports published by Lidl and from news pieces published in online newspapers. For the analysis of the data, we employed thematic coding based on the main themes established through the theoretical framework:

a) collaboration with non-traditional partners: data about the nature of the partners involved in the project, the width and breadth of the network created and the roles and responsibilities of each partner;

b) alignment with environmental trends: data about the main environmental factors with an impact on the social initiatives (i.e., legislation, economic development, trends in food consumption etc.); 
c) commitment of sufficient resources: data about the resources invested by Lidl in the project, both in terms of financial and human resources and in terms of other intangible resources such as reputation, social capital etc.;

d) alignment with organizational capabilities: data about the fit between Lidl's internal organizational culture and capabilities developed through its main retail activities, and the resources needed for the social initiative.

PICBE | 509

\section{Research results}

As a retailer, Lidl recognize its contribution to food waste and aims to take responsibility for reducing the amount of food that is wasted as a result of a mismatch between the offering of food products and the actual demand. In 2017, Lidl joined as a co-financer a project entitled "Banca pentru Alimente" (The Food Bank) through which the retailer collects both food and non-food products which are later donated directly to end consumers or used in the delivery of services by several local NGOs which cater to the needs of children and young adults with disabilities, low income elderly people, women who have been victims of abuse, families with a large number of children, single-parent families and immigrant families. The results of the social entrepreneurship initiative have been measured at 156 tones of food products collected during 2018 with a total market value of around 500,000 Euros. Based on the estimates of the reporters published by Lidl, 1 RON invested in the activity of the project results in 7 RON of social value as a result of changes in mentalities, community involvement, reduction of social exclusion, reducing costs, optimizing retail stocks and dealing with the issue of waste management in an efficient manner (IRCEM, 2019). Based on the available data and the pace of growth of the project, this can be considered a successful corporate social entrepreneurship initiative in the field of food waste. In the following pages the four main success factors are detailed.

\section{Alignment with environmental trends}

The project initiated by Lidl is well aligned with the social trends in Romania in regards to food waste. For example, there is an increased public awareness of the problem of food waste in Romania and worldwide, which can result in increased public support for initiatives aimed at reducing food waste (i.e., Lidl would gain the support of its socially conscious consumers and their loyalty). The increased awareness of the problem of food waste is demonstrated by the fact that the topic has been discussed in various local newspapers, including those with national coverage such as Gandul, Adevarul and even Libertatea (a very popular tabloid with a wide readership especially among socially disadvantaged groups) and the fact that there are numerous other social campaigns initiated by other retailers aimed at reducing food waste (e.g., the CSR project "Nu arunca painea" initiated by the La Lorraine bakery, the Tummy app which is helps restaurants reduce the amount of food thrown at the end of the day by allowing them to sell this food at discounted prices etc.). In addition, there is a high number of non-governmental organizations dealing with food scarcity issues which affect people with low or no income in Romania. For example, according to the Ministry of Labor, in Romania there are 115 social canteens spread all throughout the country (Ministerul Muncii, 2019), and, according to the Ministry of Justice, in Romania there are 94,596 nongovernmental organizations, out of which 309 (0.32\%) have as a main purpose the collection of food, clothing and other products for disadvantages groups such as children with no 
parents, elderly people, low income families, women affected by domestic abuse etc. (Ministerul Justitiei, 2019). This means that Lidl has a sufficiently large pool of nongovernmental organizations from which to choose its partners for the project and that the project overall will benefit from the public awareness of the importance of combatting food waste.

Lidl's project is also aligned with the main environmental trends related to food waste in Romania. For example, most landfills in Romania are not operating at EU standards and there is a constant threat of close down as a result of the fact that these landfills do not obey the ecological standards imposed by the EU (Pavaluca, 2018). In addition, recycling in general is at very low levels in Romania, as from the total amount of trash that ends up being collected, only 3\% is actually recycled (Ionescu, 2018), recycling knowledge is very low especially among the Romanians with low levels of education (Pelau \& Chinie, 2018), and there are no facilities for recycling food waste (except for cooking oil which is a small contributor to the total amount of food wasted). This has led to increased environmental concerns among consumers, which also applies to food waste which, after reaching landfills, contributes to environmental pollution through the release of methane in the atmosphere which is 20 times more harmful than carbon dioxide, and through the pollution of groundwater with ammonia (Sobol, 2018). This means that retailers have no viable alternatives for disposing of food products except donating them and creates the necessary incentives for other retailers to join Lidl's initiative or design their own food donating programs based on Lidl's example.

Furthermore, the timeliness of Lidl's project is underlined by its alignment with the economic trends. Romania is facing increased economic disparities and large proportions of the population is living below the poverty line with poor access to basic necessities including food (Moca-Grama, 2018). Matters are made worse by the fact that the prices for food items

have continued to increase in the past couple of decades and that Romanians, and, even if they have remained below the EU average prices for food items (Financial Intelligence, 2019), they still take up a large proportion of the household income (approximately 40\%) (Moca-Grama, 2018). This means that there is a high demand for social services that alleviate the problem of food scarcity among disadvantaged groups in Romania and that there is a high number of people that can be served by Lidl's corporate social entrepreneurship initiative. In addition, the recent changes in the legislative environment, make it easier for Lidl to allocate financial resources for the project because the project now has a direct impact on the bottom line as expenses can be deducted from the income tax paid by the company.

\section{Commitment of sufficient resources}

The main issue with social initiatives aimed at combating food waste is the lack of resources which impedes scalability and reduces the amount of social impact achieved (Moggi et al., 2018). In the case of the initiative supported by Lidl, scalability is not a major concern because the retailer has both the finances necessary in order to support the opening of food banks in other Romanian cities (from the funds it allocates on a yearly basis for CSR projects) and the logistics necessary in order to ensure that the food products are delivered to their beneficiaries in a timely manner because the retailer has operations in all major Romanian cities. The plans for 2019 are to open local food banks in four other counties: Neamt (Roman), Braila (Braila), Timis (Timisoara), Dolj (Craiova). Moreover, Lidl is using its position on the Romanian market in order to attract other retailers and food producers to 
join the initiative and donate food to the local non-governmental organizations included in the project. Besides financial and reputational resources, Lidl has also invested a host of organizational culture resources. Lidl has a strong organizational commitment towards dealing with social and environmental issues demonstrated by its previous initiatives aimed at reducing the amount of plastic used, at alleviating food scarcity (e.g., its partnership with World Vision Romania which offers a hot meal per fay for more than 1,256 children from disadvantaged areas) and at supporting local food producers (e.g., its Camara Noastra initiative).

\section{Collaboration with non-traditional partners}

Lidl has partnered with Junior Chamber International (JCI) in order to create the first Food Bank, which is an umbrella project through which various local non-governmental organizations receive donates food and use it for people with disabilities, low income elderly people, women who have been victims of abuse, families with a large number of children, single parent families and immigrant families. The first Food Bank was established in Cluj in 2016, and it was followed by the one in Bucharest which was established in 2018. JCI is an international non-governmental organization with operations in more than 124 countries. The support of JCI was very important because it facilitated the relationship between Lidl and the network of local non-governmental organizations that would receive the donated food. As a result, the terms of collaboration are as follows: Lidl helps with the promotion of the project and the collection of food items, while JCI deals with the identification of civil society partners and the allocation of food donations. The type of partnership established between Lidl and JCI is a partnership based on the internal need of Lidl to find access to resources that it did not have and it did not have the time to develop internally (i.e., knowledge of how to work with the civil sector and legitimacy as a partner for this sector). In 2018, the Food Bank from Cluj worked with 6 local non-governmental organizations and served a total of 300 beneficiaries and for 2019, the Food Bank aims to increase the number of non-governmental organizations to at least 11 and to double the number of beneficiaries.

An issue that is important for the scalability of this social entrepreneurship initiative is the growth in the amount of food and other non-food products which is collected. For example, the director of the project intends to double the amount of food products collected in 2019 and to reach at least 350 tones. Attaining this objective depends on the entrepreneur's ability to convince other companies (i.e., food producers and retailers) to join the food waste combatting initiative. At the moment, the project has 15 suppliers of products which include Metro, Danone, ETI, Unilever, Heide, Nestle, Orkla Foods Romania, Covalact and Kellogg's. Convincing suppliers to join the project meant that Lidl had to learn to collaborate in new ways with some of its traditional partners and find ways to create new partnerships that are based on the motivation of exploring the opportunities created in the external environment (i.e., the need to deal with food waste and food scarcity, the issues with waste management in Romania, the recent legislative changes etc.).

\section{Alignment with organizational capabilities}

First of all, the initiative is aligned with the logistic capabilities held by Lidl. The main food banks are located in cities were Lidl has warehouses and the expansion is also planned in cities where Lidl has stored: Neamt, Braila, Timis, and Dolj. This will make it easier for Lidl to handle the logistical aspects of the collection of food items and the delivery of these items 
to the local food banks. Second of all, Lidl has aligned the project with its organizational capabilities as the company has a well renowned reputation for the implementation of socially oriented projects. Lidl has a distinct department for PR and CSR initiatives led by Cristina Hanganu and this department plays a major role in the coordination of the resources necessary for the food waste project. Third of all, Lidl has made good use of its partnering capabilities, a reality demonstrated by the fact that Lidl's market reputation was efficiently used in order to attract important food producing companies to join the initiative.

\section{Discussion and conclusions}

It can be concluded that the factors impacting the success of corporate social entrepreneurship initiatives aimed at reducing food waste are the following: a) a clear articulation of the problem and the solution; b) the mobilization of actors from the civil society; c) continuous investment in the project; and d) the alignment of the scaling up strategy of the initiate with the main supporter's resources. Moreover, it can also be concluded that a food waste program based on the principles of corporate social entrepreneurship can generate a sustainable competitive advantage for retailers, especially in Romania where the environmental conditions are optimal for such initiatives and the rewards to be enjoyed are plentiful both in terms of cost reduction and in terms of increases in market reputation. Further studies are necessary in order to test the validity of the proposed framework for the analysis of the success of other corporate social initiatives aimed at combating food waste and to expand the framework in order to deal with scalability and sustainability issues.

\section{References}

Agrawal, A., \& Sahasranamam, S. (2016). Corporate social entrepreneurship in India. South Asian Journal of Global Business Research, 5(2), 214-233.

Aschemann-Witzel, J., de Hooge, I. E., Rohm, H., Normann, A., Bonzanini Bossle, M., Gronhoj, A., \& Oostindjer, M. (2017). Key characterstics and success factors of supply chain initiatives tackling consumer-related food waste - A multiple case study. Journal of Cleaner Production, 155(2), 33-45.

Barbu, P. (2016, November 22). România este pe locul 9 în UE la risipă alimentară. Zilnic, aruncăm o porție de mâncare la gunoi. Retrieved from: www.libertatea.ro/stiri/risipa-alimentara-romania-1664672.

Bonomi, S., Ricciardi, F., \& Rossignoli, C. (2016). "Organizational engines for smart territorial networks: The case of an initiative for food waste reduction". In: D'Ascenzo, F., Magni, M., Lazazzara, A., \& Za, S. (Eds.) Blurring the boundaries through digital innovation (pp. 247-258). Springer International Publishing.

Deacu, E. (2018, November 22). Săracii români sunt cei mai săraci dintre săracii Europei. Retrieved from: adevarul.ro/economie/bani/saracii-romani-cei-mai-saraci-saraciieuropei-1_5bf6b6dcdf52022f75b3f140/index.html.

FAO (2019). "Key facts on food loss and waste you should know!" Retrieved from: www.fao.org/save-food/resources/keyfindings/en.

Financial Intelligence (2019, June 21). "Preturile alimentelor in Romania - la 66\% din media Uniunii Europene". Retrieved from: financialintelligence.ro/preturilealimentelor-in-romania-la-66-din-media-uniunii-europene. 
Hadad, S., \& Cantaragiu, R. (2017). Corporate social entrepreneurship vs. social intraprenuership: Same idea, different trajectories? Management \& Marketing. Challenges for the Knowledge Society, 12(2), 252-276.

Ionescu, T. (2018, June 16). "Romania are a doua cea mai slaba rata de reciclare din Europa. Tara noastra produce aproape 6 milioane de deseuri/an. Cat recicleaza". Retrieved from: www.mediafax.ro/economic/romania-are-a-doua-cea-mai-slaba-rata-dereciclare-din-europa-tara-noastra-produce-aproape-6-milioane-de-tone-de-deseurian-cat-recicleaza-17256602.

IRCEM (2019). “Banca de alimente Food Waste combat Cluj”. Retrieved from: www.ircem.ro/wp-content/uploads/2019/04/PPT-banca-de-alimente-.pdf.

Maric, I., \& Knezevic, B. (2014). Social supermarkets as a new retail format inspired by social needs and philanthropy - the case of Croatia. Global Business \& Economics Anthology, 2, 278-286.

Ministerul Justitiei (2019). "Lista asociatii autorizate 2019”. Retrieved from: www.just.ro/wp-content/uploads/2015/12/Asociatii05072019.pdf

Ministerul Muncii (2019). “Cantine sociale licentiate la 11.03.2019 (cod serviciu social 8899 CDPH-I". Retrieved from: www.mmuncii.ro/j33/images/Documente/Familie/2019/11032019_Cantine_sociale. pdf.

Moca-Grama (2018, November 8). România va încerca să reducă risipa alimentară cu 50\% până în 2030. Retrieved from: www.green-report.ro/romania-va-incerca-sa-reducarisipa-alimentara-cu-50-pana-in-2030.

Moggi, S., Bonomi, S., \& Ricciardi, F. (2018). Against food waste: CSR for the social and environmental impact through a network-based organizational model. Sustainability, $10,3515$.

Mourad, M. (2016). Recycling, recovering and preventing "food waste": competing solutions for food systems sustainability in the United States and France. Journal of Cleaner Production, 126, 461-477.

Pavaluca, B. (2018, October 19). "Romania, condamnata la Curtea de Justitie a UE pentru gropile de gunoi neconforme si ilegale/ Reactia Ministerului Mediului dupa anuntarea sentintei". Retrieved from: www.mediafax.ro/externe/romania-condamnata-lacurtea-de-justitie-a-ue-pentru-gropile-de-gunoi-neconforme-si-ilegale-reactiaministerului-mediului-dupa-anuntarea-sentintei-17562573.

Pelau, C., \& Chinie, A. C. (2018). Econometric model for measuring the impact of the education level of the population on the recycling rate in a circular economy. Amfiteatru Economic, 20(48), 340-355.

Popivici, V., \& Muhnica, S. (2012). Corporate social entrepreneurship as an incubator for tomorrow's leaders. Ovidius University Annals, Economic Science Series, 12(1), 11061114.

Ribeiro, I., Sobral, P., Pecas, P., \& Henriques, E. (2018). A sustainable business model to fight food waste. Journal of Cleaner Production, 177, 262-275.

Sarti, S., Corsini, F., Gusmerotti, N. M., \& Frey, M. (2017). Food sharing: Making sense between new business models and responsible social initiatives for food waste prevention. Economics and Policy of Energy and the Environment, 1-2, 123-134.

Sobol, Z. (2018, July 26). "How food waste is harming our environment". Retrieved from: www.moveforhunger.org/how-food-waste-is-harming-our-environment. 
Voiculescu, S. (2019, February 11). Legea risipei alimentare se poate aplica, în sfârșit. Mecanismul e însă optional pentru companii. Retrieved from:

www.avocatnet.ro/articol_45643/Legea-risipei-alimentare-suspendat\%C4\%83-iarAplicarea-sa-facultativ\%C4\%83-pentru-companii.html.

Zugravu, A. (2018, August 1). Statistică privind risipa alimentară. Retrieved from: www.romania-actualitati.ro/statistica_privind_risipa_alimentara-117990. 